Provided for non-commercial research and education use. Not for reproduction, distribution or commercial use.

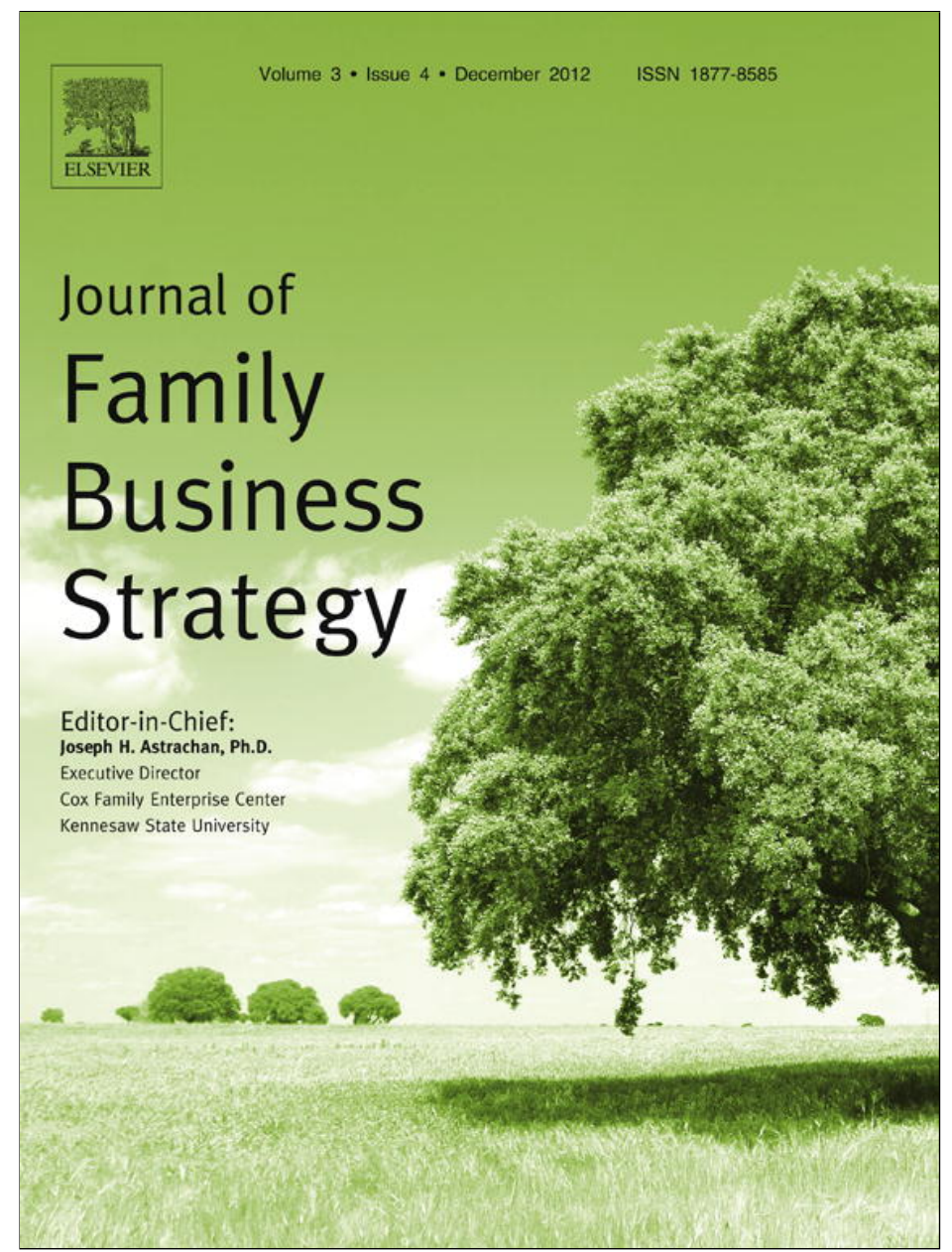

This article appeared in a journal published by Elsevier. The attached copy is furnished to the author for internal non-commercial research and education use, including for instruction at the authors institution and sharing with colleagues.

Other uses, including reproduction and distribution, or selling or licensing copies, or posting to personal, institutional or third party websites are prohibited.

In most cases authors are permitted to post their version of the article (e.g. in Word or Tex form) to their personal website or institutional repository. Authors requiring further information regarding Elsevier's archiving and manuscript policies are encouraged to visit:

http://www.elsevier.com/copyright 


\title{
Building a family firm image: How family firms capitalize on their family ties
}

\author{
Thomas M. Zellweger ${ }^{\mathrm{a}, *}$, Franz W. Kellermanns ${ }^{\mathrm{b}, \mathrm{c}, 1}$, Kimberly A. Eddleston ${ }^{\mathrm{d}, 2}$, Esra Memili ${ }^{\mathrm{e}, 3}$ \\ ${ }^{a}$ University of St. Gallen, Dufourstrasse 40a, CH-9000 St. Gallen, Switzerland \\ ${ }^{\mathrm{b}}$ Department of Management, University of Tennessee, Knoxville, TN 37919, United States \\ ${ }^{\mathrm{c}}$ INTES Center for Family Enterprises, WHU (Otto Beisheim School of Management), Germany \\ ${ }^{\mathrm{d}}$ Entrepreneurship \& Innovation Group, Northeastern University, 218 Hayden Hall, Boston, MA 02115-5000, United States \\ ${ }^{\mathrm{e}}$ Department of Marketing, Entrepreneurship, Hospitality and Tourism, University of North Carolina Greensboro, Greensboro, NC 27412, United States
}

\section{A R T I C L E I N F O}

\section{Article history:}

Received 20 March 2012

Received in revised form 20 September 2012 Accepted 2 October 2012

\section{Keywords:}

Family firm

Organizational identity

Firm image

Firm performance

\begin{abstract}
A B S T R A C T
We apply organizational identity theory to examine factors that lead family firms to create a family firm image and investigate how a family firm image impacts firm performance. We find that family firm pride, community social ties, and long-term orientation are positively associated with the inclination of a firm to portray itself as a family business to consumers and stakeholders. In turn, we find that a family firm image benefits firm performance. Thus, our study demonstrates that by building a family firm image, the unique family influences on the firm can be leveraged to create a competitive advantage for family firms.
\end{abstract} () 2012 Elsevier Ltd. All rights reserved.

\section{Introduction}

In an effort to stand out in today's competitive marketplace, firm leaders attempt to build a distinct organizational image. Organizational image captures a firm's most central, enduring and distinctive features as intentionally projected to external stakeholders by firm leaders (Whetten \& Mackey, 2002). Through advertising, communication, symbolism and branding activities, a firm projects its desired image to the public (Muzellec, 2006). The underlying assumption in building and nurturing a distinct organizational image is that it will lead to increased sales and heighten performance (Karreman \& Rylander, 2008). Recent research on family firms suggests that a family-based organizational image contributes to a family firm's ability to attract customers and increase sales (Craig, Dibbrell, \& Davis, 2008).

Recent theory that considers the dynamics of the overlapping family and business systems proposes that organizational identity may be a key source of competitive advantage for family firms since their "family identity is unique and therefore impossible to completely copy" (Sundaramurthy \& Kreiner, 2008: 416). Complementing organizational image, "organizational identity has

\footnotetext{
* Corresponding author. Tel.: +41712247100.

E-mail addresses: thomas.zellweger@unisg.ch (T.M. Zellweger), fkellermanns@cobilan.msstate.edu (F.W. Kellermanns), k.eddleston@neu.edu (K.A. Eddleston), em153@msstate.edu (E. Memili).

1 Tel.: +1 662325 2613; fax: +1 6623258651 .

2 Tel.: +1 617373 4014; fax: +1 6173732182 .

${ }^{3}$ Tel.: +1 662617 1459; fax: +1 6623258651 .
}

been conceptualized as the shared answers to the question, "Who are we as an organization?"' (Dyer \& Whetten, 2006: 788). Organizational identity refers to that which is central, enduring and distinct about an organization's character (Albert \& Whetten, 1985). However, while organizational identity is assumed to underlie an organization's image, little empirical research has examined how organizational identity or image contributes to firm performance (Dhalla, 2007; Dyer \& Whetten, 2006; Scott \& Lane, 2000). Indeed, Dyer and Whetten (2006) suggest that future research should investigate the connection between organizational identity and family firm image in understanding firm performance. While it is intuitively appealing that a family firm image may differentiate family firms in a crowded marketplace, how promoting a business as a 'family firm' enhances firm performance is unclear. It is also not understood why some firms chose to portray themselves as 'family firms' while others downplay their family firm identity.

The purpose of this article is to address these issues by developing a model of family firm image rooted in organizational identity theory. Family firm image is the intentional projection of a family business identity to external audiences. While research suggests that family members' concern for their firm's brand identity (Craig et al., 2008) influences family firm success, the processes through which a firm emphasizes its family firm image and how that impacts firm performance are not clear. We draw from the organizational identity literature (i.e. Dyer \& Whetten, 2006; Sundaramurthy \& Kreiner, 2008; Zellweger, Eddleston, \& Kellermanns, 2010) to argue that strong family firm pride, longterm orientation, and community social ties encourage family 
firms to build a pronounced family firm image. Briefly, family firm pride reflects family members' self-esteem and identification with the family firm. Long-term orientation reflects the stable nature of organizational identity and is a core value among family firms that strive to sustain the firm for future generations. Lastly, since feedback from external stakeholders is critical in forming and adjusting organizational identity and image (Bartel, 2001; Gioia, Schultz, \& Corley, 2000), and family firms are believed to possess rich social capital in their communities (Pearson, Carr, \& Shaw, 2008; Sharma, 2008), we include community social ties in our model. The more prevalent these features of organizational identity in a family firm, the stronger should be the development and deployment of a family firm image. In turn, we then argue that family firm image will positively contribute to firm performance. Thus, we draw from organizational identity theory to explore the antecedents and consequences of family firm image.

This article makes at least three contributions to the literature. First, it contributes to the family firm literature by delineating how the family and the business systems of a family firm interact to create a competitive advantage. Specifically, we examine the degree to which a family firm image contributes to firm performance. Such an investigation is important since family firms are often assumed to be concerned with their perception in the public domain (Dyer \& Whetten, 2006; Steier, 2001) and to be favorably viewed by consumers (Cooper, Upton, \& Seaman, 2005; Craig et al., 2008; Sundaramurthy \& Kreiner, 2008); yet no known study has examined the antecedents and consequences of a family firm image. Further, since some negative perceptions of family firms also exit (i.e. nepotism, stagnant, small) (Miller, Le Breton-Miller, \& Scholnick, 2008; Schulze, Lubatkin, \& Dino, 2003), it is not clear whether family firms should always be encouraged to portray a family firm image. Second, this article contributes to research on organizational identity theory by proposing and testing a theory that translates how organizational image (i.e. a firm's projected organizational identity to external parties) impacts firm performance. By applying organizational identity to the family firm realm, we are able to examine a construct of organizational image that can be broadly utilized by any family firm, and yet allows for distinctiveness given each family's unique identity and heritage. Lastly, by drawing from organizational identity theory and the family firm literature that espouses the possible advantages accrued to family businesses due to family involvement, we extend earlier research on the creation of family firm specific resources (Habbershon \& Williams, 1999; Habbershon, Williams, \& MacMillan, 2003; Pearson et al., 2008). Indeed, we believe that organizational identity theory is uniquely positioned to capture how the family can garner trust and respect in the marketplace - namely, through family firm image.

\subsection{Organizational identity theory}

Organizational identity encompasses the core values and beliefs of an organization that its members deem to be the most central, distinctive and enduring (Albert \& Whetten, 1985). Through communication, behavior and symbolism an organization reveals its identity to stakeholders (Leuthesser \& Kohli, 1997; Van Riel \& Balmer, 1997). Organizational identity reflects members' consensual view of "who we are as an organization" and "what we do as a collective" (Nag, Corley, \& Gioia, 2007). In this way, it serves both sensemaking and sensegiving functions, providing meaning to members' organizational experiences while also providing a guide for how organizational members should behave and how other organizations should relate to them (King, Felin, \& Whetten, 2010; Ravasi \& Schultz, 2006). The continuity and coherence of organizational identity enable organizational members "to satisfy their inherent needs to be the same yesterday, today and tomorrow and to be unique actors or entities" (Whetten \& Mackey, 2002: 396).
The construction of organizational identity lies in the hands of firm leaders (Karreman \& Rylander, 2008). By pursuing a unique set of goals, practices and values, firm leaders are able to use their organizational identity to create an image that differentiates their firm from others in the eyes of internal and external stakeholders. It is important that firm leaders create an attractive organizational image so as to foster organizational identification among organizational members. When organizational members see an overlap between themselves and their organization's image, and see themselves as similar to their organization, they will work to "reaffirm positive aspects of the organization in the interest of their own needs for self consistency and self-esteem" (Scott \& Lane, 2000: 48). In addition, organizational image influences external audiences' interpretation of the firm's identity goals and values (Karreman \& Rylander, 2008) thereby affecting the public's perception of the firm's products, strategies and employees (Fombrun \& Shanley, 1990). As such, organizational image provides the context within which internal and external stakeholders interpret and assign meaning to firm behavior (Ravasi \& Schultz, 2006).

Given that organizational image differentiates one organization from others in the eyes of organizational members and external audiences (King et al., 2010; Scott \& Lane, 2000), family businesses may be particularly proficient at creating unique identities since they are able to integrate elements from both the family and business domain to various degrees (Sundaramurthy \& Kreiner, 2008). Integrating the family component into the image of a family firm may provide the firm with an important and inimitable source of competitive advantage (Sundaramurthy \& Kreiner, 2008). A shared family name, common history and kinship can promote a strong, shared identity in family firms encouraging organizational members to uphold firm values and pursue firm goals (Sundaramurthy \& Kreiner, 2008). Further, being known as a "family firm" may be perceived as a positive and distinct attribute in the minds of specific classes of consumers thus contributing to firm performance. Therefore, organizational identity theory appears to be an important perspective for investigating how a family firm is able to capitalize on its unique family specific advantages.

Accordingly, we first argue that a strong family firm image enhances firm performance. Then, we draw upon organizational identity theory to explain why a family firm builds a family firm image. Because organizational identity captures "Who we are as an organization," highlighting the central and distinctive elements of a business (Albert \& Whetten, 1985; Whetten \& Mackey, 2002), we first consider family firm pride. Our view of family firm pride is in line with research on organizational identity theory that emphasizes the importance of self-esteem in promoting organizational identification (Ashforth \& Mael, 1989; Scott \& Lane, 2000). Since organizational identity is seen as enduring (Albert \& Whetten, 1985), reflecting core beliefs and values that extend over time (Gioia et al., 2000), we include long-term orientation in our examination. A long-term orientation is thought to be a common characteristic among successful family firms (i.e., Corbetta \& Salvato, 2004; Dyer \& Whetten, 2006; Miller et al., 2008) and appears to be associated with a family's concern for its image in the public's eye (Dyer \& Whetten, 2006). Lastly, because organizational identity is constructed via internal/external interaction (Gioia, 1998; Gioia et al., 2000) and research on organizational identity has stressed the importance of an organization's orientation toward independence or interdependence with external stakeholders in forming an organizational identity (Brickson, 2005, 2007), we investigate the influence of community social ties on family firm image. Social ties, which are unique in family firms since they can originate from the family or firm domain, are believed to be a key resource for family firm success (Arregle, Hitt, Sirmon, \& Very, 2007; Sirmon \& Hitt, 2003). Thus, we chose 
variables that are not only in accordance with organizational identity theory, but may also be distinct sources of competitive advantage for family firms. Fig. 1 summarizes our hypothesized relationships. Below we begin by discussing why family firm image is expected to be positively related to firm performance. We then proceed by presenting the proposed antecedents of family firm image.

\subsection{Family firm image and its link to performance}

Organizational image is "what organizational agents want their external stakeholders to understand is most central, enduring and distinctive about their organization" (Whetten \& Mackey, 2002: 401). It provides firm leaders with the opportunity to communicate organizational identity by creating a sense of meaning and portraying symbols of the organization that can be recognized by stakeholders (Karreman \& Rylander, 2008; Scott \& Lane, 2000). An organization's image is intentionally projected to external audiences and is often tied to an organization's goals and strategies (Dyer \& Whetten, 2006; Fombrun \& Shanley, 1990; Gilpin, 2008; Hudson, 2008). In constructing their organization's image, firm leaders intend to differentiate their organization from others. According to the institutional approach to organizational identity, firm leaders share their views of what an organization is and represents within the organization by providing organizational members with consistent narratives that allow members to construct a collective sense of self and provide meaning to their organizational experience (Gilpin, 2008; Ravasi \& Schultz, 2006). As such, image creating activity is an integral part of organization identity construction "since it serves the dual purpose of making public what is special, unique or distinctive about organizations" to stakeholders "while simultaneously providing the mechanisms through which managers explore what an organization is about that is, what its core values and its central beliefs are" (Scott \& Lane, 2000: 45).

The focus of our article is on organizational image and this construct is distinct, albeit related to reputation. While organizational image focuses on the portrayal of a firm to external stakeholders (Hudson, 2008), organizational reputation is "a particular type of feedback, received by organizations from their stakeholders, concerning the credibility of the organization's identity claims" (Whetten \& Mackey, 2002: 401). Economic models of reputation view marketing efforts as imaging cues designed to influence the perceptions of external audiences (Fombrun \& Shanley, 1990). A positive organizational reputation can be a source of competitive advantage that allows a firm to charge premium prices (e.g., Klein \& Leffler, 1981), attract new clients (Fombrun, 1996), enhance access to capital markets (Beatty

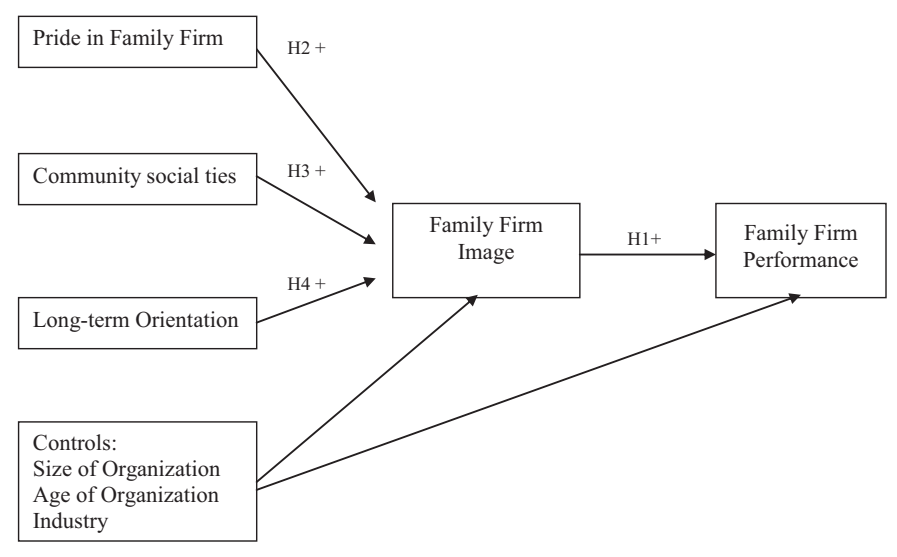

Fig. 1. Antecedents of family firm image and performance.
\& Ritter, 1986) and sustain market share during industry downturns (Fombrun, 1996). In an effort to increase sales, firms compete for reputational status (Fombrun \& Shanley, 1990) and work to create an organizational image that will build a reputation that is seen as favorable, strong and unique in the minds of customers (Karreman \& Rylander, 2008; King \& Whetten, 2008). As such, while a firm projects its organizational identity to external stakeholders through its image, reputation captures how those stakeholders interpret and perceive that image.

Zellweger et al. (2010) suggest that a family firm image contributes to firm performance both through alterations inside and outside the firm. Inside the firm, family managers have been found to go to great lengths to build and support a favorable family firm image, because the intertwined identities create a rallying ground and incentive to support the firm. As a family firm grows and ages a strong family firm image may act as a critical resource that fosters connection and synergy between the family and firm. Consequently, a strong family firm image may inspire ethical decision-making (Berrone, Cruz, Gomez-Mejia, \& Larraza-Kantana, 2010; Dyer \& Whetten, 2006) and a sense of obligation on the part of family members to support the goals and strategies of the firm (Zellweger et al., 2010, in press).

Given that organizational image differentiates one organization from others in the eyes of organizational members and external audiences (King et al., 2010; Scott \& Lane, 2000), family businesses may be particularly proficient at creating unique identities since they are able to integrate elements from both the family and business domain (Sundaramurthy \& Kreiner, 2008). This allows for unique branding strategies that emphasize the firm's family ties as exemplified by firms such as SC Johnson in the US or Hipp in Europe. In this way the family comes to personify the business, becoming an external resource for the firm that is inimitable, unique and recognizable in the marketplace. Indeed, it has been suggested that developing a family-based brand identity positively contributes to firm growth and profitability due to its influence on customer-centered values (Craig et al., 2008). Businesses that promote a family firm image may be able to capitalize on customers' positive perception of family firms since these firms are seen as trustworthy (Tagiuri \& Davis, 1996; Ward \& Aronoff, 1995), customer-focused and quality driven (Cooper et al., 2005; Sundaramurthy \& Kreiner, 2008). Further, the benefits of projecting a family firm image may accrue not only with customers but also with a broader range of stakeholders. Specifically, a family firm image, which is associated with being seen as trustworthy, socially responsible and quality-driven (i.e. Craig et al., 2008; Dyer \& Whetten, 2006; Tagiuri \& Davis, 1996), may create an extended family of stakeholders (e.g., suppliers, business partners) who support the principles of the family and the firm, such as loyalty, fairness and respect. Such close ties with stakeholders benefit the business since they give access to timely and trustworthy information critical for business operations, and tend to facilitate funding and attract business opportunities (Sieger, Zellweger, Nason, \& Clinton, 2011; Uzzi, 1997).

However, not all family firms choose to portray a family image nor do their leaders, owners or employees define the firm as a 'family firm' (Westhead \& Howorth, 2007; Zellweger et al., 2010). Recent research applying organizational identity theory has acknowledged that family firms have two relevant identities the family and the business - that can be segmented or integrated to different degrees (Sundaramurthy \& Kreiner, 2008). On the one hand, businesses like SC Johnson that portray their firm as " $\mathrm{A}$ Family Company" can be seen as having a highly integrated identity, where the family and business identities are intermingled and highlighted to stakeholders. In contrast, some family businesses choose to ignore or downplay their family firm status, resembling non-family firms. Perhaps the (mis)perception that 
family firms are resistant to change and stagnant (Eddleston, Kellermanns, \& Sarathy, 2008; Miller et al., 2008) causes these firms to avoid building an image as a family firm. Perhaps some family firms resist proclaiming their family firm status because they want to be perceived as professionally managed and not burdened with family issues such as nepotism and particularism. For example, some family firms (e.g. Mars) appear to downplay or even hide their family ties. Yet, because an organizational identity can be an important and inimitable source of competitive advantage, and a family's identity is unique and thus impossible to completely copy (Sundaramurthy \& Kreiner, 2008), we argue that a strong family firm image will be associated with greater firm performance. Therefore:

Hypothesis 1. Family firm image is positively related to family firm performance.

\subsection{Family pride}

Family firm pride captures the esteem and respect family members possess toward their family firm. Although it can be seen as similar to the concepts of organizational commitment and psychological ownership, it is distinct in that organizational commitment seeks to answer the question: "Should I maintain membership in this organization and why?," psychological ownership answers the question: "What do I feel is mine?," (Pierce, Kostova, \& Dirks, 2001) while pride addresses the question: "How do I feel about others knowing that I am a member of this organization?" Pride is unique in that it reflects concern for outward appearances and acceptance, alerting others that one deserves greater status and approval (Tracy, 2004). Given pride's apparent regard for others' opinions, we believe that family firm pride may influence a family firm's decision to create a strong family firm image. When family members believe their firm, its history or even their family are impressive, they may be more inclined to construct a family firm image. In contrast, when family members are embarrassed of their family firm's past or family affiliation, they may be more likely to hide their family firm status (Litz \& Turner, in press). Drawing upon organizational identity theory, we explain below how pride may affect family firm image and performance, thus hypothesizing that family firm image mediates the relationship between family firm pride and performance.

Identity theory purports that pride is an important consequence of heightened identification with an organization or group (Ashforth \& Mael, 1989). Cable and Turban (2003) note that people derive pride from organizational membership and that employers are an important part of employees' self-concept (Brown \& Marshall, 2001; Dutton, Dukerich, \& Harquail, 1994). Theory and research suggest that organizational members' individual identity is closely linked to their organization's identity (e.g., Ashforth \& Mael, 1989; Dutton et al., 1994; Scott \& Lane, 2000). In particular, people who perceive their organizations as attractive and are highly connected and visible members of their firms, are most likely to strongly identify with their organizations (Ashforth \& Mael, 1989; Dutton et al., 1994). The need for selfconsistency, self-esteem and pride leads firm leaders to construct an organizational image that they believe will enhance goal attainment and is in line with their sense of self (Scott \& Lane, 2000). Indeed, Scott and Lane (2000) suggest that the most effective firm leaders are driven to build a positive organizational image because their personal pride overlaps with their organization's identity.

Pride may be an important element to family firms since the successes, accomplishments and triumphs of one family member can become a shared identity and history for the entire family
(Ward \& Aronoff, 1995). Further, family firm pride may be particularly enduring and strong given the family element. For example, Ashforth discusses how identities are most strongly formed and endured when they are enacted in a "local, tribal context" (1998: 279) and Fiske (1991) acknowledges the strength and enactment among close kin. It has been suggested that because their self-esteem is tied to their identification with their family and firm, many family firm leaders make a concerted effort to build a positive organizational image (Miller et al., 2008). Family firms are conscious of the fact that a bad public image could "soil the good name of the family" (Dyer \& Whetten, 2006: 791). Thus, family firm pride should be positively associated with a family firm image.

It is also argued that family firm pride will positively affect firm performance. Family ties create an emotional bond and sense of commitment that encourage family members to pursue a common set of goals (Sundaramurthy \& Kreiner, 2008). "Fulfilling family obligations can be a source of pride, serve as an important nonmonetary incentive, and provide a common rallying ground for members of the family firm" (Sundaramurthy \& Kreiner, 2008: $425)$. Research on organizational identity theory suggests that individuals who strongly identify with their organizations feel an increased sense of responsibility for the organization (Dipboye, 1977) and provide helpful and supportive behaviors to their firms (Dutton et al., 1994). Similarly, employee morale encourages organizational members to exert extra effort to achieve firm goals (Gunter \& Furnham, 1996) and organizational pride has been found to be an important component of job satisfaction which thereby contributes to the performance of the firm (Smithey-Fulmer, Gerhardt, \& Scott, 2003). Furthermore, Sundaramurthy and Kreiner (2008) suggest that strong family firm pride causes family members to police one another's behavior, contributing to firm performance. Since organizational pride has been suggested to be associated with organizational prestige (Smidts, Pruyn, \& Van Riel, 2001), families that are prominent and prestigious may have an advantage at raising money and attracting and retaining customers (Steier, 2001). Family firm pride may also encourage family members to invest in the family business, fostering growth and prosperity. As such, family firm pride is expected to have a positive influence on firm performance.

Taken together, our arguments suggest that the effect of family firm pride on performance occurs primarily through the benefits of a family firm image. That is, the esteem and respect family members possess toward their firm is expected to translate into high firm performance through the reflections of a positive family firm image to stakeholders. Hence, we expect that family firm image mediates the relationship between family firm pride and firm performance.

Hypothesis 2. The relationship between family firm pride and performance is mediated by family firm image.

\subsection{Community social ties}

Organizational identity is believed to be affected by external stakeholders (i.e., Gioia, 1998; Gioia et al., 2000; Smidts et al., 2001 ) whereby organizational members develop and refine their organizational identity based on information gathered from external parties (Hatch \& Schultz, 2002). This view of organizational identity "builds on the idea that identity is a relational construct formed in interaction with others" (Hatch \& Schultz, 2002: 992). Because individuals aim to accentuate their organization's distinctiveness, social comparisons are an important means through which organizational members build their organizational identity (Bartel, 2001). Social interactions with external stakeholders assist in making an individual's organizational identity more salient and distinct (Bartel, 2001). It is through social 
interactions with external parties that organizational members come to learn about the public's expectations and perceptions of the organization (Dutton et al., 1994). In turn, the perception of how external stakeholders view the organization is expected to influence an organization's image (Dhalla, 2007; Gioia \& Thomas, 1996). Accordingly, social ties in one's community may act as a mirror for organizations - showing firm leaders how the public views the firm as well as how the firm is distinct from other firms in the community. As such, social ties may assist in the development of a distinct organizational identity and therefore creation of a unique organizational image. Below, we therefore link community social ties to family firm image and then performance so as to hypothesize family firm image as a mediator.

Firms often align themselves in a community with like-minded organizations, and in the case of family firms - often other family firms (Lester \& Cannella, 2006). Through linkages to other firms, family firms develop shared language, norms and core values, learning how family firms are expected to behave (Lester \& Cannella, 2006). Frequent interactions allow parties to know one another, share important information, and create a common point of view (Tsai \& Ghoshal, 1998; Walter, Lechner, \& Kellermanns, 2007). As family firms interact with other firms in their community, they may then come to appreciate their unique family heritage and the importance of family within their organizational identity. Because social comparisons promote sensemaking and information gathering (Bartel, 2001), community social ties may help family firms to understand the socially desirable features the public often associates with family firms. Consequently, the perception of how the community views the firm is expected to strengthen family firm image.

Specifically, family firms often work to build strong social ties in their communities so that not only the current but also the next generation can benefit from accrued trust, cooperation and social capital (i.e. Lester \& Cannella, 2006; Sirmon \& Hitt, 2003). For instance, family firms have been found to benefit from lower cost of debt financing since the business relationship between the family firm (borrower) and bank (lender) often extends across time and generations (Anderson, Mansi, \& Reeb, 2003). Additionally, a family firm's support for the community tends to be reciprocated over time through the loyalty of lenders, customers, employees, suppliers, and further stakeholders (Niehm, Swinney, \& Miller, 2008). Such firms understand the importance of goodwill and social capital derived from their communities and therefore these firms make a concerted effort to build a positive family firm image (Miller et al., 2008). Furthermore, due to their personal involvement in the family firm, family leaders are able to develop more consistent, durable and credible relationships with community leaders, banks and other local organizations (Arregle et al., 2007; Carney, 2005; Lounsbury \& Glynn, 2001; Sirmon \& Hitt, 2003). Community ties are seen as an important mechanism through which family leaders protect and nurture their businesses (Lester \& Cannella, 2006), helping them to build a positive organizational image. Indeed, membership in a community network has been argued to enhance a family firm's image (Lester \& Cannella, 2006; Salvato \& Melin, 2008; Sharma, 2008) which is in line with social capital research that suggests that community involvement is an investment in a firm's image (Spence, Schmidpeter, \& Habisch, 2003). Thus, strong community ties should enhance a family firm image.

Subsequently, building on research on the importance of social capital to family firms, we argue that community social ties will positively affect family firm performance. Social capital refers to the "sum of the actual and potential resources embedded within, available through, and derived from" social ties within a network (Nahapiet \& Ghoshal, 1998: 243). Within the family business literature, it has been proposed that family firms are often capable of deriving rich social capital since it is naturally embedded within the idiosyncratic family unit and the ties the family has with external stakeholders (Arregle et al., 2007; Pearson et al., 2008). Additionally, the establishment of strong social ties not only benefits current family members but also future generations (Sirmon \& Hitt, 2003).

Specifically, through a diverse set of social ties, an organization may gain access to other organization's resources and knowledge (Powell, Koput, \& Smith-Doerr, 1996; Tsai \& Ghoshal, 1998) as well as customer and supplier referrals, business advice and capital, and access to opportunities that can lower risk and increase capabilities (Chang, Memili, Chrisman, Kellermanns, \& Chua, 2009; Jack, Dodd, \& Anderson, 2004; Peredo \& Chrisman, 2006). Family firms with strong social ties in their communities are more easily able to communicate the value of their goods and services to potential customers and to garner strategic resources (Sirmon \& Hitt, 2003). Given that relational exchanges and trust are built over time, the complex networks and enduring relationships that family firms build within their communities can be a primary source of competitive advantage (Miller et al., 2008; Sirmon \& Hitt, 2003; Sorenson, Folker, \& Brigham, 2008; Steier, 2001). Indeed, family firms that have strong social ties are expected to compete more effectively than those that lack social ties (James, 1999; Sharma, 2008; Sirmon \& Hitt, 2003). Additionally, the personal responsibility that well-connected family business leaders often feel for their communities can push them to grow their businesses so as to benefit their local area and townspeople (Stavrou, 1998). Therefore, we propose:

Hypothesis 3. The relationship between community social ties and performance is mediated by family firm image.

\subsection{Long-term orientation}

A long-term orientation refers to an organizational culture that favors patient investments in long-term and sometimes risky activities (Hitt, Hoskisson, Johnson, \& Moesel, 1996; Zahra, Hayton, \& Salvato, 2004). A long-term orientation is thought to be prevalent in family firms and many family firms can be characterized as displaying longer-term planning horizons (e.g., Burkart, Pannunzi, \& Shleifer, 2003; James, 1999; Miller \& Le Breton-Miller, 2006; Miller et al., 2008; Sirmon \& Hitt, 2003; Zellweger, 2007). In particular, maintaining the business for future generations is often an important goal for family firms (e.g., Gómez-Mejía, Haynes, Núñez-Nickel, Jacobson, \& Moyano-Fuentes, 2007; Kets de Vries, 1993; Ward, 1997). Family firm leaders dream of passing on a legacy to their posterity as well as a sustainable income stream for future generations (Dyer \& Whetten, 2006). A long-term orientation is complementary to the long time spans advocated by successful family businesses (Corbetta \& Salvato, 2004) and has been depicted as a unique resource for family firms (Sirmon \& Hitt, 2003). This depiction of long-term orientation as a distinct core value of many family firms is in line with recent research on organizational identity theory that demonstrates how organizational identity not only creates meaning for work practices, but also guides organizational behavior and decision-making (Nag et al., 2007). Accordingly, below we draw upon organizational identity theory to argue that a long-term orientation will influence a family firm's image and performance. We then hypothesize that family firm image mediates the relationship between long-term orientation and firm performance.

Core features of organizational identity are presumed to be resistant to "faddish attempts to alteration because of their ties to the organization's history" (Gioia et al., 2000: 64). Although it is possible for an organizational identity to be reframed or reinterpreted, the core beliefs and values that comprise an 
organizational identity extend over time and context (Gioia et al., 2000). Organizational identity reflects an organization's unique features and how it reveals its values through communication and behaviors (Muzellec, 2006). As such, organizational identity builds upon a firm's heritage while also setting a course for the firm's future. It is about behavior as much as it is about appearance (Muzellec, 2006). With this in mind, a long-term orientation may reflect an enduring value of family firms that contributes to their success.

Specifically, in working to create a long lasting successful firm, family firm leaders often build companies that are resistant to faddish trends (Craig et al., 2008), instead choosing to promote the longstanding nature of the family firm with continuous family involvement and steadfast investment strategies. For example, the concern for the long haul encourages family firm leaders to focus on building customer loyalty (Miller et al., 2008) and an image that stresses quality and customer-service (Sundaramurthy \& Kreiner, 2008). A long-term orientation should encourage family firms to protect their family name and image of their firm in the public's eye (Dyer \& Whetten, 2006). Those family firms that emphasize long-term strategies may be more likely to see a family firm image as an investment in their future. In this way, building a family firm image may help family firms to leverage their patient investments and long-term strategies by demonstrating to external stakeholders that they are here for the long haul and committed to serving their long-term needs. When family firms make advertising statements like "Our family serving yours for the last three generations," organizational identity theory would suggest that they are proclaiming their enduring family involvement and their longstanding commitment to serving customers - in the past, present and future. Therefore, we argue that a long-term orientation is positively related to a family firm image.

Furthermore, because fast-growth, high performing family firms have been found to develop long-term goals and strategies (Upton, Teal, \& Felan, 2001) and advocate long-term financial performance (McCann, Leon-Guerrero, \& Haley, 2001), a long-term orientation may contribute to family firm success. Because the firm can be seen as a vehicle to nurture the family's future through jobs, security and income for the next generation, the long-term orientation of family firms is believed to push them to invest in the business for continued prosperity and growth (Gómez-Mejía et al., 2007; Miller et al., 2008). Long-term orientation fosters enduring relationships with key stakeholders, particularly customers (Aronoff \& Ward, 1995; Dick \& Basu, 1994; Habbershon \& Williams, 1999; Lyman, 1991). Zahra et al. (2004: 363) also note that a long-term orientation allows family firms to "dedicate resources required for innovation and risk taking, thereby fostering entrepreneurship." Because these firms are not subjected to shortterm performance pressures, they are able to create investment portfolios that have higher performance potential in the long run (Miller \& Le Breton-Miller, 2005; Zellweger, 2007). In long-term oriented firms, family members may be more apt to put aside the pursuit of short-term personal gains for the well-being of the family firm. Indeed, long-term investments and long-term planning appear to promote the success of family firms across generations (Zahra et al., 2004). For example, when firms establish long-term relationships with customers, customers tend to purchase more, spend less time in the purchasing process, be less price sensitive, and influence other potential customers to purchase (Reichheld, 1996). In accordance with this set of arguments, we propose that a family firm image mediates the relationship between long-term orientation and firm performance.

Hypothesis 4. The relationship between long-term orientation and performance is mediated by family firm image.

\section{Method}

We used mail-surveys to collect our data, which is consistent with prior research on family firms (e.g., Eddleston et al., 2008; Schulze et al., 2003). We obtained a mailing list of privately held family businesses from a family business center at a major Swiss university. These businesses defined themselves as family firms through their affiliation with the family business center. Additionally, for all firms in the study ownership lied within the family and at least two family members were employed by the business. After one follow-up mailing, 179 firms participated, resulting in a $14.3 \%$ response rate, which is satisfactory for privately held firms (e.g., Chrisman, Chua, Chang, \& Kellermanns, 2007; Eddleston \& Kellermanns, 2007). This data was collected as part of a larger data collection effort (see Memili, Eddleston, Zellweger, Kellermanns, \& Barnett, 2010; Zellweger, Kellermanns, Chrisman, \& Chua, 2012).

In order to ensure a high level of response quality, we relied on key informants (Kumar, Stern, \& Anderson, 1993; Seidler, 1974). Rather than choosing respondents randomly, we focused on the family CEO with an ownership stake in the firm to gain in-depth knowledge about organizational image, performance, and associated antecedents. Note that we collected data from two respondents for a subset of the sample (39 pairs) to validate our key-informant approach. For all variables in the study, the $r_{\mathrm{wgs}}$ were acceptable, indicating that a key respondent approach was appropriate for the study.

\subsection{Measures}

All constructs were measured using Likert-type scales with a 7point response format ranging from "strongly disagree" to "strongly agree." For the individual items, factor loadings, Average Variance Extracted (AVE) scores and the construct reliabilities of the associated constructs, please refer to Appendix A. Our measure of long-term orientation was adapted from Zellweger (2007) and based on the impact of an increased time horizon on strategic opportunities of firms. Our items assessing the respondent's family firm pride were adapted from Smithey-Fulmer et al. (2003). To measure community social ties, we followed Tsai and Ghoshal (1998) and measured social resources embedded not only in interfirm relationships but also in close relationships with community leaders and social organizations. Our measure of family firm image was developed by Memili et al. (2010) and is based on the research of Craig et al. (2008) and Dyer and Whetten (2006). Our measure converges on Craig et al.'s (2008) family based brand identity subscale. ${ }^{4}$ To improve the AVE scores, we dropped two items from Memili et al. (2010); however, the regression results were robust with either conceptualization.

For performance, we utilized five performance-related questions. Multiple performance indicators were warranted due to the underlying multidimensionality of the performance construct (e.g., Cameron, 1978). We stress that subjective performance measures are often utilized due to the lack of objective data for companies that are not publicly traded (Love, Priem, \& Lumpkin, 2002). Prior research has shown that such subjective measures of performance are correlated with objective performance data in family firms (Ling \& Kellermans, 2010). Individual performance measures were added to calculate overall performance, with higher values indicating better performance (e.g., Dess \& Robinson, 1984; Eddleston \& Kellermanns, 2007). A prior study by Memilli and colleagues (2010) drawing on the same database also showed a

\footnotetext{
${ }^{4}$ For further considerations about the appropriateness and limitations of our image measure, refer to Section 4
} 
marginally positive relationship between family firm image and growth related performance measures.

We utilized seven different control variables in our study. First, we controlled for industry level effects with five dummy codes because family firm image may be more important in certain industries than others (Capon, Farley, \& Hoenig, 1990). Second, we controlled for family firm age to address any liability of newness concerns (Stichcombe, 1965) that may negatively affect the ability to build and leverage a firm's image. Third, we controlled for firm size, as larger firms may have more resources to invest in image related activities.

\subsection{Assessment of construct validity and reliability}

To assess the validity and reliability of our five constructs, we performed a confirmatory factor analysis (CFA). Values exceeding .90 for the incremental fit index (IFI) and comparative fit index (CFI) are seen as indicating acceptable fit (Hu \& Bentler, 1995, 1999; Mulaik et al., 1989). Our analysis resulted in an IFI of .951, CFI of $.950, \chi^{2}$ of 202.554 and $\chi^{2} / D F$ ratio of $1.478 . \chi^{2} /$ DF ratios below 5 indicate good fit (Bollen \& Long, 1993). Further, the root mean square error of approximation (RMSEA) for the model was .047, which is below the .08 threshold level, indicating good fit ( $\mathrm{Hu} \&$ Bentler, 1995, 1999; Mulaik et al., 1989). In summary, all of these measures indicate adequate fit according to recommended guidelines (Hair, Black, Babin, \& Anderson, 2010).

Several criteria were used to assess the validity and reliability of the constructs (see Appendix A). The average variance extracted (AVE) for two constructs is below the recommended 50\% level. However, convergent validity can nevertheless be considered acceptable, given that content validity is demonstrated and reliabilities are acceptable. With regard to reliability, three of the five constructs exhibit reliability levels that meet or exceed the .7 threshold level, and the other two are relatively close, indicating good construct reliability, particularly for exploratory research (Hair et al., 2010).

Discriminant validity was assessed by comparing the AVE scores to the squared inter-construct correlations (not reported). The established guideline is that the AVE score for each construct should be greater than the corresponding squared inter-construct correlations (Hair et al., 2010). This condition was met in all cases, with the exception of Pride and Family Firm Image, where the AVE scores for the two constructs were somewhat lower than the corresponding squared interconstruct correlations. A post hoc face validity assessment by a panel of experts demonstrated that the constructs are measuring different concepts. Moreover, a large amount of shared variance between the two constructs was expected based on theoretical considerations since the relationship was between endogenous and exogenous constructs. Lastly, nomological validity was assessed by inspecting the direction of the relationships among constructs with regard to extant theory (Hair et al., 2010). The significant construct correlations are consistent with theory, thus establishing nomological validity.

Although we found only moderate levels of correlation between our variables, we centered the variables (Cronbach, 1987), calculated variance inflation factors (all $<2.173$ ) and condition indices (all $<28.658$ ) to check for multicollinearity. All indices were below the suggested threshold level (Hair et al., 2010). We then tested for common method bias as suggested by Podsakoff and Organ (1986). We entered the items of the independent and mediator variables into a factor analysis and extracted five factors with Eigenvalues $>1.0$, which accounted for $64.17 \%$ of the variance. The first factor accounted for $26.49 \%$ of the variance, while the remaining factors accounted for $37.69 \%$ of the variance. Therefore, common method bias does not appear to be a problem in our study.

\section{Results}

The means, standard deviations, and zero-order correlations are shown in Table 1 . We tested the hypotheses via multiple regression analysis. The results are shown in Table 2 .

In Model 1, performance was regressed on the control variables. In the second model, performance was regressed on our independent variables. All independent variables showed a significant or marginally significant relationship to performance. Pride in the family firm $(\beta=.112, p<.10)$, community social ties $(\beta=.172, p<.05)$, and long-term orientation $(\beta=.275, p<.001)$ positively affected family firm performance. In a third model, we regressed performance on family firm image $(\beta=.299, p<.001)$, which supports Hypothesis 1 . Since the mediator was significant as well, the initial preconditions for meditation were fulfilled. In the next step (model 4), we tested the independent variables' significance in relation to the mediator. Pride in the family firm $(\beta=.566, p<.001)$, community social ties $(\beta=.118, p<.05)$, and long-term orientation $(\beta=.157, p<.01)$ were significant predictors of family firm image. In the final step (model 5 ), to test for full or partial mediation, we regressed performance on all variables. The mediator was found to be significant $(\beta=.195, p<.05$ ), while the significance of all other variables was reduced. Overall, the relationship between family firm pride and performance was fully mediated, while the relationship between community social ties

Table 1

Descriptive statistics and correlations.

\begin{tabular}{|c|c|c|c|c|c|c|c|c|c|c|c|c|c|}
\hline Variables & Mean & SD & 1. & 2. & 3. & 4 & 5. & 6. & 7. & 8. & 9. & 10. & 11. \\
\hline 1. Construction-related industries & .26 & .44 & & & & & & & & & & & \\
\hline 2. Wood processing-related industries & .07 & .26 & $-.17^{*}$ & & & & & & & & & & \\
\hline 3. Engineering-related industries & .10 & .30 & $-.20^{* *}$ & -.09 & & & & & & & & & \\
\hline 4. Service-related industries & .29 & .45 & $-.39^{* * *}$ & $-.18^{*}$ & $-.21^{* *}$ & & & & & & & & \\
\hline 5. Manufacturing-related industries & .12 & .31 & $-.23^{* *}$ & -.11 & -.12 & $-.24^{* * *}$ & & & & & & & \\
\hline 6. Family firm age & 69.08 & 38.08 & $.18^{*}$ & -.08 & -.05 & $-.31^{* *}$ & .12 & & & & & & \\
\hline 7. Family firm size (employees) & 340.97 & 1907.52 & -.06 & -.03 & -.05 & -.07 & $.26^{* * *}$ & .03 & & & & & \\
\hline 8. Family firm pride & 5.77 & .98 & .09 & $-.17^{*}$ & -.08 & -.03 & .13 & $.17^{*}$ & .09 & & & & \\
\hline 9. Community social ties & 5.46 & .97 & .09 & $-.17^{*}$ & .08 & -.04 & -.06 & $.12^{\dagger}$ & .05 & $.22^{* *}$ & & & \\
\hline 10. Long-term orientation & 4.30 & 1.10 & $-.15^{*}$ & .00 & .03 & .05 & .03 & .02 & .09 & .10 & .09 & & \\
\hline 11. Family firm image & 4.82 & 1.28 & $.13^{\dagger}$ & -.11 & -.11 & -.07 & $.16^{*}$ & $.26^{* * *}$ & .07 & $.64^{* * *}$ & $.26^{* * *}$ & $.21^{* *}$ & \\
\hline 12. Family firm performance & 4.51 & 1.19 & $-.20^{* *}$ & $-.15^{*}$ & .04 & .08 & $.17^{*}$ & -.01 & $.15^{\dagger}$ & $.20^{* *}$ & $.22^{* *}$ & $.34^{* * *}$ & $.28^{* * *}$ \\
\hline
\end{tabular}

$N=179$

$\dagger p<.10$.

$* p<.05$.

** $p<.01$.

${ }^{* * *} p<.001$. 
Table 2

OLS regression results.

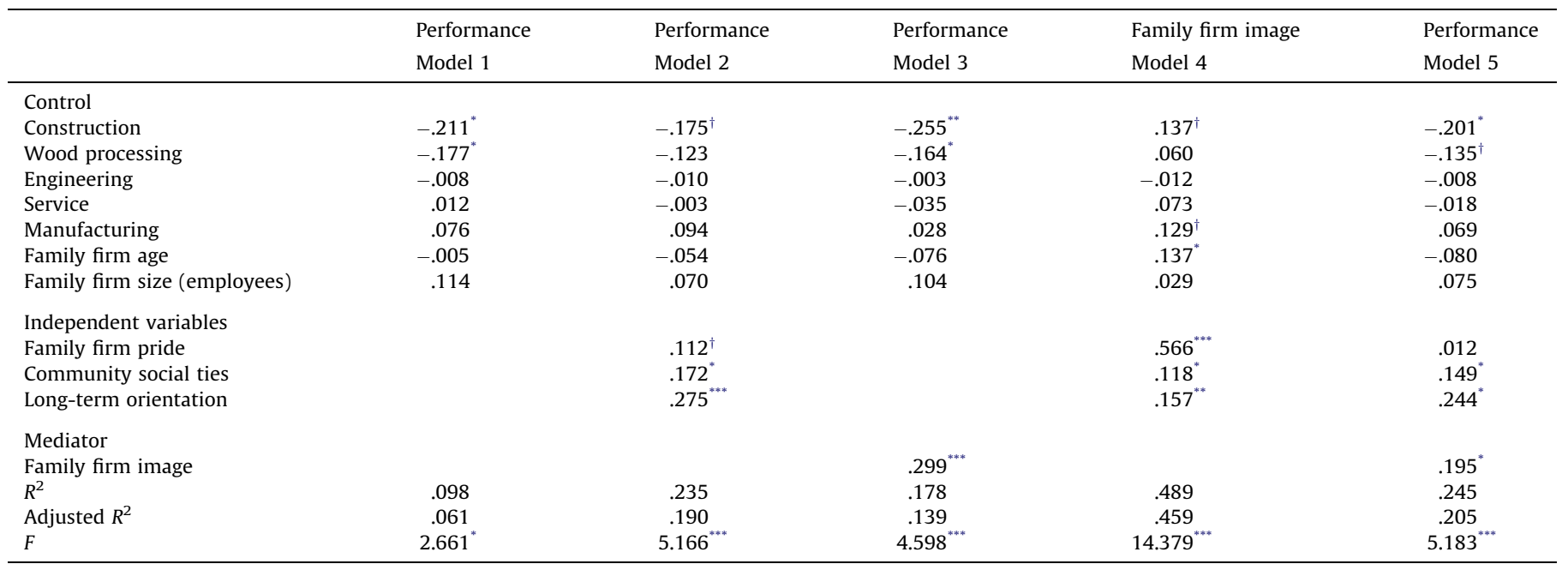

$N=179$.

$p<.10$

${ }_{* *}^{*} p<.05$.

$p<.01$.

$p<.001$.

and long-term orientation and performance was partially mediated be family firm image, which lends support to Hypotheses 2-4.

\section{Discussion}

Based on organizational identity theory, our study set out to investigate the impact of family firm image on firm performance and also to explore antecedents of family firm image. Recent research has proposed that family members' concern for the public's perception of the business may serve as motivation that thereby leads them to outperform their non-family firm counterparts (Anderson \& Reeb, 2003; Craig et al., 2008). We sought to extend this research by investigating why some family firms choose to create a stronger family firm image than others and in turn, if a strong family firm image contributes to performance. Our study indeed shows that family firm image is positively related to firm performance. Hence, it appears that seeking to nurture stakeholders' perception of a business as a family firm allows the business to create a positive cognitive image of the organization that positively affects firm performance. As such, our study complements the research by Craig et al. (2008) and Memilli and colleagues (2010) by showing that the promotion of a business as a family firm generates success on a variety of performance dimensions. Accordingly, family firm image can be seen as a unique competitive advantage for family firms.

Additionally, by applying organizational identity to the family firm realm, we have been able to examine a construct of organizational image that can be broadly utilized by any family firm while also allowing for distinctiveness given each family's unique identity and heritage. By drawing from organizational identity theory to propose three antecedents of family firm image, we were able to provide a nuanced perspective regarding why family firms vary in the extent to which they portray a family firm image. Our study showed that differences in family firm pride, community social ties and long-term orientation predict the pronouncement of a family firm image. More specifically, we found that family firm pride has a positive impact on family firm image and in turn performance, albeit only a marginally significant main effect on performance. We, therefore, suggest that when family members believe in their firm and its history, they tend to be more inclined to construct a strong family firm image that can be exploited through the promotion of the business as a family firm in the market place.

Our study also shows that community social ties have a positive impact on performance through family firm image. In line with recent suggestions that identities are socially constructed (Nag et al., 2007) and that they emerge from interactions with internal and external stakeholders (Scott \& Lane, 2000), strong community social ties were found to nurture a family firm image, which in turn strengthened performance. This result adds to the wider literature that explores the relationship between social ties and performance. While social ties can influence firm performance in a variety of ways (Arregle et al., 2007), our study suggests that one way family firms can benefit from strong social ties is through the development of a family firm image. Given our findings, more research is needed that explores how strong community social ties encourage family firms to build a family firm image, and how this, in turn, benefits their performance within the community.

Lastly, we show that family firm image partially mediates the relationship between long-term orientation and performance. Although research shows that an organizational identity can be partly mutable and reinterpreted over time (Gioia et al., 2000), because an organizational identity builds upon a firm's heritage and history, it is resistant to attempts of alteration. Family firms with a long-term orientation may be particularly proficient at creating a coherent and enduring image for their businesses. Family firms that are patient and prefer long-term investment strategies may decide to build a family firm image so as to communicate their stable family heritage and traditional values. Perhaps this is a reason why family firms are often seen as trustworthy. Additionally, our results indicate that long-term orientation directly affects family firm performance, after taking into account family firm image. Given the pivotal role of a long-term orientation for family firms (Gómez-Mejía et al., 2007), future research is certainly needed.

Taken together our findings elaborate on differences among family firms and how family firms differ in the degree to which they express their family ties. We believe this is an important step toward understanding the heterogeneity among family firms and the complexity of building and expressing a family firm identity. 
Recent theorizing has suggested that not all objectively defined family firms (i.e. firms that researchers would define as family firms) see themselves as such and that some family firms choose to downplay their family ties due to negative stereotypes associated with family involvement like nepotism and particularism (Zellweger et al., 2010). Yet new advances in family firm research suggest that a family firm brand can be a competitive advantage due to positive perceptions of family firms among consumers (Craig et al., 2008). We believe that our study addresses these inconsistencies by demonstrating that a strong family firm image is associated with greater firm performance. However, we also acknowledge that our study creates additional questions that call for attention. For example, are there certain contexts when a strong family firm image is harmful, perhaps when seeking venture capitalists and investors or when competing in high-tech industries? On the other hand, are there contexts when a family firm image is particularly beneficial, for example when forming international partnerships with other family firms? Further, it would be interesting to study how a family firm image evolves over time, especially as different generations take leadership of the firm. Thus, research such as ours (i.e. Craig et al., 2008; Sundaramurthy \& Kreiner, 2008; Zellweger et al., 2010) is just beginning to understand the impact of a family firm identity and image.

\section{Limitations and implications}

We need to mention a few limitations of our study. First, our study is situated in Switzerland. On one hand, in a small country such as Switzerland community social ties and firm image may be essential to business activity thereby biasing results. These biases, however, may be offset by the relative openness and the international scope of economic activity in Switzerland. The fact that we developed several measures may be seen as a further limitation. For instance, our family firm image measure may be challenged as it seems to combine items that capture image and reputation. For example, the items ("The family firm name is recognized in the community"; "Most of our customers know that we are a family business") could be considered the family firm's perception of their reputation since the items refer to external stakeholders. However, these items are from the perception of family firm leaders and therefore they do not capture external stakeholders' actual view of the business. Further, our measure appears to be valid for two additional reasons: first, we conducted an exploratory factor analysis which supports the choice of a single factor structure. Second, we believe that our measure captures image and not reputation because the items are self-assessments by the family firm leaders and not external stakeholders, which would be necessary to measure reputation. Still, future researchers should refine and further validate these measures. It would be interesting for future research to explore how family firm image affects a firm's reputation in the marketplace. Are there scenarios where a very strong (or weak) family firm image hurts a firm's reputation? Does a family firm's reputation vary by stakeholders? That is, can a strong family firm image translate into a positive reputation for some stakeholders but a negative reputation for others? Hopefully, our study inspires additional research on these issues.

An additional limitation of our study refers to the fact that our sample came from a business center and thus, may be biased by an overrepresentation of firms for which their family owners experience pride and hence emphasize a family firm image. Even though endogeneity does not seem to be a significant issue in our study (analysis not reported here), it is possible that family firms for which their owners do not feel pride, for instance because of the unethical behavior of a previous family generation (Litz \& Turner, in press), are sold or terminated. We also need to mention that our data collection is cross-sectional and that it therefore poses the threat of common method bias. However, results from the single factor test (Podsakoff \& Organ, 1986) should diminish these concerns. Research suggests that while common method bias may be present, it does not significantly affect results or conclusions (e.g., Doty \& Glick, 1998). Still, future research would benefit from a longitudinal design. A longitudinal study could assess how a family firm's image evolves and also how family firm image and reputation may influence one another, and perhaps co-evolve, over time. In addition, we need to acknowledge that two of our constructs, long-term orientation and community social pride, have low AVEs and future research should improve upon our measures. Finally, our performance indicator was self-reported. While we encourage future research to utilize objective performance data, these objective measures were not available for the firms in our study since they are not publicly traded. However, prior research has shown that self-reported and actual performance measures in family firms are correlated (Ling \& Kellermans, 2010).

In addition to the future research opportunities we stated above, our study provides several other avenues for future investigation. While we focus on the benefits of a family firm image, it would be interesting to explore if a family firm image could harm a family firm in certain scenarios. Driven by the need to maintain a consistent identity, family firms might be particularly challenged when faced with a turbulent environment or identity threat (Elsbach \& Kramer, 1996). Identity has often been depicted as a relatively enduring organizational feature that impedes strategic change, mainly because members are viewed as avoiding learning to preserve existing conceptions of themselves and their organizations (Brown \& Starkey, 2000). Studies on organizational identity and strategic change have highlighted the problems organizations face in changing their identities when faced with new imperatives (Bartunek, 1984; Gioia \& Thomas, 1996; Nag et al., 2007). Indeed, it has been argued that a family firm image may have a dark side when it comes to adaptation and overcoming identity threats (Keller, 1993; Sundaramurthy \& Kreiner, 2008). For example, are there certain industries, particularly dynamic and innovative industries, where it could be harmful to utilize a family firm image?

Aside from the antecedents of family firm image we have investigated in our study, other possible antecedents of family firm image can be investigated. For instance, harmony and conflicts between family members (Kellermanns \& Eddleston, 2004) and forms of commitment in family firms (e.g., Sharma \& Irving, 2005) may affect family firm image. In addition, other organizational outcomes of family firm image such as marketing strategy (e.g., Knight, 2000), diversification (Gómez-Mejía, Makri, \& LarrazaKintana, 2010), or non-financial performance/goals could be investigated (e.g., Zellweger \& Astrachan, 2008). Indeed, a nonfamily firm is expected to be driven solely or primarily by economic goals, whereas a family firm is expected to take a more balanced set of economic and non-economic goals, such as preservation of socioemotional wealth, into account when setting strategies (GómezMejía et al., 2007, 2010). As such, it would be interesting to explore how family firm image affects a firm's socioemotional wealth.

Also, there is increasing evidence that organizational identity and image are part of family firm owners' ultimate goal (Berrone et al., 2010; Dyer \& Whetten, 2006; Zellweger et al., in press). In this case, a family firm image is not only a means to achieve performance, but high performance can also attribute to stronger family firm image. Similarly, strong family firm performance may enhance family firm pride, community social ties, and long-term orientation. As such, the causality between performance and image could be reversed or the relationship could be reciprocal. This is an area ripe for future research. 
Our study has several implications for theory. First, we add to the growing literature that explores how family involvement in business activity affects performance. Other scholars have applied the resource based view (e.g., Habbershon \& Williams, 1999; Sirmon \& Hitt, 2003), stewardship theory (e.g., Eddleston \& Kellermanns, 2007) or agency theory (e.g., Schulze et al., 2003). However, we provide one of the first empirical investigations of the performance of family firms using an organizational identity theory lens. Organizational identity is a difficult concept to compare among firms given each firm's unique characteristics. However, the family firm context provides a unique laboratory to test the tenets of organizational identity theory since each firm can be compared in regard to the strength of its family firm image while also allowing for the distinct characteristics of each family firm identity. As such, we contribute to organizational identity theory by introducing three drivers of a family firm image that are based on organizational identity theory and the family firm literature. Beyond assertions that stakeholders have an impact on organizational identity (Scott \& Lane, 2000), we do not know enough about the drivers of a firm's image. To date, literature has conceptually stressed the impact of strategic issues and threats on image and identity (Dutton et al., 1994; Ravasi \& Schultz, 2006), the relative stability of the identity and image concept (Gioia et al., 2000), how organizational identities impact resources (Nag et al., 2007), and how management of identity boundaries can contribute to governance in family firms (Sundaramurthy \& Kreiner, 2008). We move beyond this research by investigating the antecedents and outcomes of family firm image.

\section{Conclusion}

Based on organization identity theory, we test the impact of family firm image on family firm performance. We show that family firm pride, community social ties, and long-term orientation are important antecedents to family firm image. Accordingly, our study adds to organizational identity theory in general and to our understanding of family firms in particular. We hope that our study will trigger additional family firm research that will utilize this promising theoretical lens.

\section{Appendix A. Scale items}

\begin{tabular}{|c|c|c|c|c|}
\hline Construct & Items & $\begin{array}{l}\text { Factor } \\
\text { loading }^{\text {a }}\end{array}$ & $\mathrm{AVE}^{\mathrm{b}}$ & $\mathrm{CR}^{\mathrm{c}}$ \\
\hline & Independent variables & & & \\
\hline \multirow[t]{4}{*}{ Long-term orientation } & $\begin{array}{l}\text { Our family firm pursues } \\
\text { multiple investment projects } \\
\text { and then waits to see how } \\
\text { they evolve over time. }\end{array}$ & .44 & .36 & .68 \\
\hline & $\begin{array}{l}\text { Our family firm is able to } \\
\text { invest in projects that take a } \\
\text { longer time to see financial } \\
\text { returns. }\end{array}$ & .42 & & \\
\hline & $\begin{array}{l}\text { Our family firm is able to } \\
\text { invest in projects that are less } \\
\text { profitable than those pursued } \\
\text { by its competitors. }\end{array}$ & .68 & & \\
\hline & $\begin{array}{l}\text { Our family firm pursues } \\
\text { investment projects that are } \\
\text { riskier than the ones of its } \\
\text { competitors. }\end{array}$ & .79 & & \\
\hline \multirow[t]{3}{*}{ Pride in family firm } & $\begin{array}{l}\text { I am proud to work for this } \\
\text { family firm. }\end{array}$ & .50 & .53 & .76 \\
\hline & $\begin{array}{l}\text { I really care about the fate of } \\
\text { this organization. }\end{array}$ & 63 & & \\
\hline & $\begin{array}{l}\text { The family members are } \\
\text { proud to work for this firm. }\end{array}$ & .97 & & \\
\hline
\end{tabular}

\begin{tabular}{|c|c|c|c|c|}
\hline Construct & Items & $\begin{array}{l}\text { Factor } \\
\text { loading }^{\mathrm{a}}\end{array}$ & $\mathrm{AVE}^{\mathrm{b}}$ & $\mathrm{CR}^{\mathrm{c}}$ \\
\hline \multirow[t]{4}{*}{ Community social ties } & $\begin{array}{l}\text { The family firm is well } \\
\text { connected to community } \\
\text { leaders. }\end{array}$ & .57 & \multirow[t]{4}{*}{.35} & \multirow[t]{4}{*}{.68} \\
\hline & $\begin{array}{l}\text { The family firm has good } \\
\text { banking relationships. }\end{array}$ & .55 & & \\
\hline & $\begin{array}{l}\text { The family firm is active in } \\
\text { business networks (e.g. trade } \\
\text { associations) or social } \\
\text { organizations (Lions, Rotary, } \\
\text { Kiwanis). }\end{array}$ & .60 & & \\
\hline & $\begin{array}{l}\text { The family firm is well } \\
\text { connected to other firms. } \\
\text { Mediator }\end{array}$ & .64 & & \\
\hline \multirow[t]{4}{*}{ Family firm image } & $\begin{array}{l}\text { In our advertisement, we } \\
\text { mention that we are a family } \\
\text { business. }\end{array}$ & .67 & \multirow[t]{4}{*}{.54} & \multirow[t]{4}{*}{.78} \\
\hline & $\begin{array}{l}\text { Most of our customers know } \\
\text { that we are a family business. }\end{array}$ & .74 & & \\
\hline & $\begin{array}{l}\text { The fact that we are a family } \\
\text { business is a great marketing } \\
\text { tool. }\end{array}$ & .79 & & \\
\hline & Dependent variable & & & \\
\hline \multirow[t]{5}{*}{ Family firm performance } & $\begin{array}{l}\text { I feel that our firm makes a } \\
\text { good financial profit. }\end{array}$ & .82 & \multirow[t]{5}{*}{.50} & \multirow[t]{5}{*}{.83} \\
\hline & $\begin{array}{l}\text { We have strong growth } \\
\text { opportunities in our firm. }\end{array}$ & .58 & & \\
\hline & $\begin{array}{l}\text { We have a good return on the } \\
\text { invested equity capital. }\end{array}$ & .88 & & \\
\hline & $\begin{array}{l}\text { The shareholders have good } \\
\text { dividends from the firm. }\end{array}$ & .62 & & \\
\hline & $\begin{array}{l}\text { The family has financial } \\
\text { freedom thanks to the firm's } \\
\text { financial outcomes. }\end{array}$ & .57 & & \\
\hline
\end{tabular}

\footnotetext{
a Standardized regression weights obtained by AMOS.

b Average variance extracted.

c Construct reliability.
}

\section{References}

Albert, S., \& Whetten, D. A. (1985). Organizational identity. In L. L. Cummings \& B. M Staw (Eds.), Research in organizational behavior, Vol. 7 (pp. 263-295). Greenwich, CT: JAI Press.

Anderson, R., \& Reeb, D. (2003). Founding-family ownership and firm performance: Evidence from S\&P 500. Journal of Finance, 58(3), 1301-1327.

Anderson, R. C., Mansi, S. A., \& Reeb, D. M. (2003). Founding family ownership and the agency cost of debt. Journal of Financial Economics, 68(2), 263-285.

Aronoff, C. E., \& Ward, J. L. (1995). Family-owned businesses: A think of the past or a model of the future? Family Business Review, 8(2), 121-130.

Arregle, J.-L., Hitt, M. A., Sirmon, D. G., \& Very, P. (2007). The development of organizational social capital: Attributes of family firms. Journal of Management Studies, 44, 72-95.

Ashforth, B. E. (1998). Becoming: How does the process of identification unfold? In D. A Whetten \& P. C. Godfrey (Eds.), Identity in organizations: Developing theory through conversation (pp. 213-222). Thousand Oaks, CA: Sage Publications.

Ashforth, B. E., \& Mael, F. (1989). Social identity theory and the organization. Academy of Management Review, 14, 20-39.

Bartel, C. A. (2001). Social comparisons in boundary-spanning work: Effects of community outreach on members' organizational identity and identification. Administrative Science Quarterly, 46, 379-413.

Bartunek, J. M. (1984). Changing interpretive schemes and organizational restructuring: Th example of religious order. Administrative Science Quarterly, 29, 355-372.

Beatty, R. P., \& Ritter, J. R. (1986). Investment banking, reputation, and the underpricing of initial public offerings. Journal of Financial Economics, 15, 213-232.

Berrone, P., Cruz, C., Gomez-Mejia, L. R., \& Larraza-Kintana, M. (2010). Socioemotional wealth and corporate responses to institutional pressures: Do family-controlled firms pollute less? Administrative Science Quarterly, 55(1), 82-113.

Bollen, K. A., \& Long, J. S. (1993). Introduction. In K. A. Bollen \& J. S. Long (Eds.), Testing structural equation models. London: Sage Publications, Inc.

Brickson, S. L. (2005). Organizational identity orientation: Forging a link between organizational identity and organizations' relations with stakeholders. Administrative Science Quarterly, 50(4), 576-609.

Brickson, S. L. (2007). Organizational identity orientation: The genesis of the role of the firm and distinct forms of social value. Academy of Management Review, 32(3), $864-888$.

Brown, A. D., \& Starkey, K. (2000). Organizational identity and learning: A psychodynamic perspective. Academy of Management Review, 25(1), 102-120. 
Brown, J. D., \& Marshall, M. A. (2001). Self-esteem and emotion: Some thoughts about feelings. Personality and Social Psychology Bulletin, 27, 575-584.

Burkart, M., Pannunzi, F., \& Shleifer, A. (2003). Family firms. Journal of Finance, 58, 2167-2202.

Cable, D. M., \& Turban, D. B. (2003). The value of organizational reputation in the recruitment context: A brand-equity perspective. Journal of Applied Social Psychology, 33(11), 2244-2266.

Cameron, K. (1978). Measuring organizational effectiveness in institutions of higher education. Administrative Science Quarterly, 23(4), 604-632.

Capon, N., Farley, J. U., \& Hoenig, S. (1990). Determinants of financial performance: A meta analysis. Management Science, 36(10), 1143-1159.

Carney, M. (2005). Corporate governance and competitive advantage in family-controlled firms. Entrepreneurship Theory and Practice, 29(3), 249-266.

Chang, E. P. C., Memili, E., Chrisman, J., Kellermanns, F. W., \& Chua, J. (2009). Venture preparation and business creation: Does family help? A report of Hispanics in the U.S.. Family Business Review, 22(3), 279-292.

Chrisman, J. J., Chua, J. H., Chang, E. P., \& Kellermanns, F. W. (2007). Are family managers agents or stewards? An exploratory study in privately-held family firms. Journal of Business Research, 60, 1030-1038.

Cooper, M. J., Upton, N., \& Seaman, S. (2005). Customer relationship management: A comparative analysis of family and nonfamily business perspectives. Journal of Small Business Management, 43(3), 242-256.

Corbetta, G., \& Salvato, C. (2004). Self-serving or self-actualizing? Models of man and agency costs in different types of family firms: A commentary on "Comparing the agency costs of family and non-family firms: Conceptual issues and exploratory evidence". Entrepreneurship Theory and Practice, 28(4), 355-362.

Craig, J., Dibbrell, C., \& Davis, P. S. (2008). Leveraging family-based brand identity to enhance firm competitiveness and performance in family businesses. Journal of Small Business Management, 46(3), 351-371.

Cronbach, L. J. (1987). Statistical tests for moderator variables: Flaws in analyses recently proposed. Psychological Bulletin, 102(3), 414-417.

Dess, G. G., \& Robinson, R. B. (1984). Industry effects and strategic management research. Journal of Management, 16(7), 7-27.

Dhalla, R. (2007). The construction of organizational identity: Key contributing external and intra-organizational factors. Corporate Reputation Review, 10(4), 245-260.

Dick, A. S., \& Basu, K. (1994). Customer loyalty: Toward an integrated conceptual framework. Journal of the Academy of Marketing Science, 22(2), 99-113.

Dipboye, R. L. (1977). A critical review of Korman's self-consistency theory of work motivation and occupation choice. Organizational Behavior and Human Performance, 18, 108-126.

Doty, D. H., \& Glick, W. H. (1998). Common methods bias: Does common methods variance really bias results? Organizational Research Methods, 1, 374-406.

Dutton, J. E., Dukerich, J. M., \& Harquail, C. V. (1994). Organizational images and member identification. Administrative Science Quarterly, 39, 239-263.

Dyer, W. G., Jr., \& Whetten, D. A. (2006). Family firms and social responsibility: Preliminary evidence from the S\&P 500. Entrepreneurship Theory and Practice, 30(6), 785-802.

Eddleston, K., \& Kellermanns, F. W. (2007). Destructive and productive family relationships: A stewardship theory perspective. Journal of Business Venturing, 22(4), 545-565.

Eddleston, K., Kellermanns, F. W., \& Sarathy, R. (2008). Resource configuration in family firms: Linking resources, strategic planning and technological opportunities to performance. Journal of Management Studies, 45(1), 26-50.

Elsbach, K. D., \& Kramer, R. M. (1996). Members' responses to organizational identity threats: Encountering and countering the Business Week rankings. Administrative Science Quarterly, 41, 442-476.

Fiske, A. P. (1991). Structures of social life: The four elementary forms of human relations. NY: Free Press Macmillan.

Fombrun, C. J. (1996). Reputation: Realizing value from the corporate image. Boston, MA: Harvard Business School Press.

Fombrun, C. J., \& Shanley, M. (1990). What's in a name? Reputation building and corporate strategy. Academy of Management Journal, 33(1), 233-258.

Gilpin, D. R. (2008). Narrating the organizational self: Reframing the role of the news release. Public Relations Review, 34, 9-18.

Gioia, D. (1998). From individual to organizational identity. In D. Whetten \& P. Godfrey (Eds.), Identity in organizations: Building theory through conversations (pp. 17-31). Thousand Oaks, CA: Sage.

Gioia, D. A., Schultz, M., \& Corley, K. G. (2000). Organizational identity, image, and adaptive instability. Academy of Management Review, 25(1), 63-81.

Gioia, D. A., \& Thomas, J. B. (1996). Identity, image, and issue interpretation: Sensemaking during strategic change in academia. Administrative Science Quarterly, 41,370-403.

Gómez-Mejía, L. R., Haynes, K. T., Núñez-Nickel, M., Jacobson, K. J. L., \& MoyanoFuentes, H. (2007). Socioemotional wealth and business risk in family-controlled firms: Evidence from Spanish olive oil mills. Administrative Science Quarterly, 52(1), 106-137.

Gómez-Mejía, L., Makri, M., \& Larraza-Kintana, M. (2010). Diversification Decisions in Family-Controlled Firms. Journal of Management Studies, 47(2), 223-252.

Gunter, B., \& Furnham, A. (1996). Biographical and climate predictors of job satisfaction and pride in organizations. Journal of Psychology, 130(2), 193-208.

Habbershon, T. G., \& Williams, M. (1999). A resource-based framework for assessing the strategic advantage of family firms. Family Business Review, 12, 1-25.

Habbershon, T. G., Williams, M., \& MacMillan, I. C. (2003). A unified systems perspective of family firm performance. Journal of Business Venturing, 18, 451-465.

Hair, J. F., Jr., Black, W. C., Babin, B. J., \& Anderson, R. E. (2010). Multivariate data analysis (7th ed.). Upper Saddle River: Pearson.

Hatch, M. J., \& Schultz, M. (2002). The dynamics of organizational identity. Human Relations, 55(8), 989-1018.
Hitt, M. A., Hoskisson, R. E., Johnson, R. A., \& Moesel, D. D. (1996). The market for corporate control and firm innovation. Academy of Management Journal, 39(5), 1084-1119.

Hu, L. T., \& Bentler, P. M. (1995). Evaluating model fit. In R. H. Hoyle (Ed.), Structural equation modeling: Concepts, issues, and applications (pp. 76-99). Thousand Oaks, CA: Sage.

Hu, L., \& Bentler, P. M. (1999). Cutoff criteria for fit indexes in covariance structure analysis: Conventional criteria versus new alternatives. Structural equation modeling, 6(1), 1-55.

Hudson, B. A. (2008). Against all odds: A consideration of core-stigmatized organizations. Academy of Management Review, 33(1), 252-266.

Jack, S. L., Dodd, S. D., \& Anderson, A. R. (2004). Social structures and entrepreneurial networks: The strength of strong ties. The International Journal of Entrepreneurship and Innovation, 5(2), 107-120.

James, H. (1999). Owner as manager, extended horizons and the family firm. International Journal of Economics of Business, 6, 41-56.

Karreman, D., \& Rylander, A. (2008). Managing meaning through branding-The case of a consulting firm. Organization Studies, 29(1), 103-125.

Keller, K. L. (1993). Conceptualizing, measuring and managing customer-based brand equity. Journal of Marketing, 57(1), 1-22.

Kellermanns, F. W., \& Eddleston, K. (2004). Feuding families: When conflict does a family firm good. Entrepreneurship Theory and Practice, 28(3), 209-228.

Kets de Vries, M. F. R. (1993). The dynamics of family controlled firms: The good and the bad news. Organizational Dynamics, 21(3), 59-71.

King, B. G., Felin, T., \& Whetten, D. A. (2010). Finding the organization in organizational theory: A meta-theory of the organization as a social actor. Organization Science, 21(1), 290-305.

King, B. G., \& Whetten, D. A. (2008). Rethinking the relationship between reputation and legitimacy: A social actor conceptualization. Corporate Reputation Review, 11(3), 192-207.

Klein, B., \& Leffler, K. B. (1981). The role of market forces in assuring contractual performance. The Journal of Political Economy, 89(4), 615-642.

Knight, G. (2000). Entrepreneurship and marketing strategy: The SME under globalization. Journal of International Marketing, 8(2), 12-32.

Kumar, N., Stern, L. W., \& Anderson, J. C. (1993). Conducting interorganizational research using key in-formants. Academy of Management Journal, 36(6), 16331651.

Lester, R. H., \& Cannella, A. A. (2006). Interorganizational familiness: How family firms use interlocking directorates to build community-level social capital. Entrepreneurship Theory \& Practice, 30(6), 755-775.

Leuthesser, L., \& Kohli, C. (1997). Corporate identity: The role of mission statements. Business Horizons, 40(3), 59-66.

Ling, Y., \& Kellermans, F. (2010). The effects of family firm specific sources of TMT diversity: The moderating role of information exchange frequency. Journal of Management Studies, 47(2), 322-344.

Litz, R., \& Turner, N. Sins of the father's firm: Exploring responses to ethical dilemmas in family business. Journal of Business Ethics; http://dx.doi.org/10.1007/s10551-012$1305-7$, in press.

Lounsbury, M., \& Glynn, M. A. (2001). Cultural entrepreneurship: Stories, legitimacy, and the acquisition of resources. Strategic Management Journal, 22, 545-564.

Love, L. G., Priem, R. L., \& Lumpkin, G. T. (2002). Explicitly articulated strategy and firm performance under alternative levels of centralization. Journal of Management, 28(5), 611-627.

Lyman, A. R. (1991). Customer service: Does family ownership make a difference? Family Business Review, 4(3), 303-324.

McCann, J. E., Leon-Guerrero, A. Y., \& Haley, J. D. (2001). Strategic goals and practices of innovative family businesses. Journal of Small Business Management, 39(1), 50-59.

Memili, E., Eddleston, K. H., Zellweger, T., Kellermanns, F. W., \& Barnett, T. (2010). The Critical Path to Family Firm Success through Entrepreneurial Risk Taking and Image. Journal of Family Business Strategy, 1(4), 200-209.

Miller, D., \& Le Breton-Miller, I. (2005). Managing for the long run: Lessons in competitive advantage from great family businesses. Boston, MA: Harvard Business School Press.

Miller, D. \& Le Breton-Miller, I. (2006). Priorities, practices and strategies in successful and failing family businesses: An elaboration and test of the configuration perspective. Strategic Organization, 4(4), 379-407.

Miller, D., Le Breton-Miller, I., \& Scholnick, B. (2008). Stewardship vs. stagnation: An empirical comparison of small family and non-family businesses. Journal of Management Studies, 45(1), 51-78.

Mulaik, S. A., James, L. R., Alstine, J. V., Bennett, N., Ling, S., \& Stilwell, C. D. (1989). Evaluation of goodness-of-fit for structural equation models. Psychological Bulletin, 105(3), 430-445.

Muzellec, L. (2006). What is in a name change? Re-joycing corporate names to create corporate brands. Corporate Reputation Review, 8(4), 305-316.

Nag, R., Corley, K. G., \& Gioia, D. A. (2007). The intersection of organizational identity, knowledge, and practice: Attempting strategic change via knowledge grafting. Academy of Management Journal, 50(4), 821-847.

Nahapiet, J. \& Ghoshal, S. (1998). Social capital, intellectual capital, and the organizational advantage. Academy of Management Review, 23(2), 242-266.

Niehm, L. S., Swinney, J., \& Miller, N. J. (2008). Community social responsibility and its consequences for family business performance. Journal of Small Business Management, 46(3), 331-350.

Pearson, A. W., Carr, J. C., \& Shaw, J. C. (2008). Toward a theory of familiness: A social capital perspective. Entrepreneurship Theory and Practice, 32(6), 949-969

Peredo, A.-M., \& Chrisman, J. J. (2006). Toward a theory of community-based enterprise. Academy of Management Review, 31(2), 309-328. 
Pierce, J. L., Kostova, T., \& Dirks, K. T. (2001). Toward a theory of psychological ownership. Academy of Management Review, 26(2), 298-310.

Podsakoff, P. M., \& Organ, D. W. (1986). Self-reports in organizational research: Problems and perspectives. Journal of Management, 12, 531-544.

Powell, W. W., Koput, K. W., \& Smith-Doerr, L. (1996). Inter-organizational collaboration and the locus of innovation: Networks of learning in the biotechnology. Administrative Science Ouarterly, 41, 116-145.

Ravasi, D., \& Schultz, M. (2006). Responding to organizational identity threats: Exploring the role of organizational culture. Academy of Management Journal, 49(3), 433-458.

Reichheld, F. F. (1996). Learning from customer defections. Harvard Business Review, 74(2), 56-69.

Salvato, C., \& Melin, L. (2008). Creating value across generations in family-controlled businesses: The role of family social capital. Family Business Review, 21(3), 259-277.

Schulze, W. S., Lubatkin, M. H., \& Dino, R. N. (2003). Exploring the agency consequences of ownership dispersion among the directors of private family firms. Academy of Management Journal, 46(2), 179-194.

Scott, S. G., \& Lane, V. R. (2000). A stakeholder approach to organizational identity. Academy of Management Review, 25(1), 43-62.

Seidler, J. (1974). On using key informants: A technique for collecting quantitative data and controlling measurement error in organization analysis. American Sociological Review, 39(December), 816L 831.

Sharma, P. (2008). Commentary: Familiness: Capital stocks and flows between family and business. Entrepreneurship Theory and Practice, 32(6), 971-977.

Sharma, P., \& Irving, P. G. (2005). Four bases of family business successor commitment: Antecedents and consequences. Entrepreneurship Theory \& Practice, 20, 13-33.

Sieger, P., Zellweger, T., Nason, R., \& Clinton, E. (2011). Portfolio entrepreneurship in family firms: A resource-based perspective. Strategic Entrepreneurship Journal, 5(4), 327-351.

Sirmon, D. G., \& Hitt, M. A. (2003). Managing resources: Linking unique resources, management and wealth creation in family firms. Entrepreneurship Theory and Practice, 27(4), 339-358.

Smidts, A., Pruyn, A. H., \& Van Riel, C. B. M. (2001). The impact of employee communication and perceived external prestige on organizational identification. Academy of Management Journal, 49(5), 1051-1062.

Smithey-Fulmer, I., Gerhardt, B., \& Scott, K. S. (2003). Are the 100 best better? An empirical investigation of the relationship between being a great place to work and firm performance. Personnel Psychology, 56, 965-993.

Sorenson, R. L., Folker, C. A., \& Brigham, K. H. (2008). The collaborative network orientation: Achieving business success through collaborative relationships. Entrepreneurship: Theory and Practice, 32(4), 615-634.

Spence, L. J., Schmidpeter, R., \& Habisch, A. (2003). Assessing social capital: Small and medium sized enterprises in Germany and the UK. Journal of Business Ethics, 47(1), $17-29$.

Stavrou, E. P. (1998). A four factor model: A guide to planning next generation involvement in the family firm. Family Business Review, 11(2), 135-142.
Steier, L. (2001). Family firms, plural forms of governance, and the evolving role of trust. Family Business Review, 14(4), 353-367.

Stichcombe, A. L. (1965). Social structure and organizations. In J. G. March (Ed.) Handbook of organizations (pp. 142-193). Chicago: Rand McNally \& Company.

Sundaramurthy, C., \& Kreiner, G. E. (2008). Governing by managing identity boundaries: The case of family businesses. Entrepreneurship Theory \& Practice, 32(3), 415-436.

Tagiuri, R., \& Davis, J. A. (1996). Bivalent attributes of the family firm. Family Business Review, 9(2), 199-208.

Tracy, J. L. (2004). Show your pride: Evidence for a discrete emotion expression. Psychological Science, 15(3), 194-197.

Tsai, W., \& Ghoshal, S. (1998). Social capital and value creation: The role of intrafirm networks. Academy of Management Journal, 41(4), 464-476.

Upton, N., Teal, E. J., \& Felan, J. T. (2001). Strategic and business planning practices of fast growth family firms. Journal of Small Business Management, 39(1), 60-72.

Uzzi, B. (1997). Social structure and competition in interfirm networks: The paradox of embeddedness. Administrative Science Quarterly, 42, 35-67.

Van Riel, C. B. M., \& Balmer, J. M. T. (1997). Corporate identity: The concept, its measurement and management. European Journal of Marketing, 31(5/6), 340-355.

Walter, J., Lechner, C., \& Kellermanns, F. W. (2007). Knowledge transfer between and within alliance partners: Private versus collective benefits of social capital. Journal of Business Research, 60, 698-710.

Ward, J., \& Aronoff, C. E. (1995). Family-owned businesses: A thing of the past or a model for the future. Family Business Review, 8(2), 121-130.

Ward, J. L. (1997). Growing the family business: Special challenges and best practices. Family Business Review, 10, 323-337.

Westhead, P., \& Howorth, C. (2007). 'Types' of private family firm: An exploratory conceptual and empirical analysis. Entrepreneurship \& Regional Development, 19, 405-431.

Whetten, D., \& Mackey, A. (2002). A social actor conception of organizational identity and its implications for the study of organizational reputation. Business and Society, 41(4), 393-415

Zahra, S. A., Hayton, J. C., \& Salvato, C. (2004). Entrepreneurship in family vs. non-family firms: A resource-based analysis of the effect of organizational culture. Entrepreneurship Theory \& Practice, 28(4), 363-381.

Zellweger, T. (2007). Time horizon, costs of equity capital and generic investment strategies of firms. Family Business Review, 20(1), 1-15.

Zellweger, T., \& Astrachan, J. (2008). On the emotional value of owning a firm. Family Business Review, 21(4), 347-363.

Zellweger, T., Eddleston, K., \& Kellermanns, F. W. (2010). Exploring the concept of familiness: Introducing family firm identity. Journal of Family Business Strategy, $1(1), 54-63$

Zellweger, T., Nason, R., Nordqvist, M., \& Brush, C. Why do family firms strive for nonfinancial goals? An organizational identity perspective. Entrepreneurship The ory \& Practice; http://dx.doi.org/10.1111/j.1540-6520.2011.00466.x, in press.

Zellweger, T., Kellermanns, F., Chrisman, J., \& Chua, J. (2012). Family Control and Family Firm Valuation by Family CEOs: The Importance of Intentions for transgenerational Control. Organization Science, 23(3), 851-868. 